TILTAI, 2016, 1, 171-189, ISSN 1392-3137 (Print), ISSN 2351-6569 (Online)

\title{
VYRŲ BENAMYSTE் NAKVYNĖS NAMUOSE IR GATVĖJE: IŠGYVENIMO NARATYVAI
}

\author{
Violeta Ivanauskienė, Natalja Gončiarova \\ Vytauto Didžiojo universitetas,
}

Kauno technologijos universiteto inžinerijos licejjus

\begin{abstract}
Anotacija
Straipsnyje analizuojamos benamių vyrų išgyvenimo nakvynès namuose ir gatvejje strategijos. Benamiams paprastai trūksta socialinių ir ekonominių išteklių, todèl jų kasdienis išgyvenimas susijęs su viltimi patenkinti minimalius poreikius: susirasti pastogę ir maisto, apsisaugoti nuo šalčio ir smurto. Išgyvenimas šiame straipsnyje analizuojamas kaip asmenų taikomos strategijos ir veiksmai, siekiant išlikti benamystès situacijoje. Pristatomas empirinis tyrimas, kuriuo siekta išsiaiškinti, kaip benamiai vyrai konstruoja siekị išgyventi benamystę nakvynès namuose ir gatvejje. Tyrimo rezultatai atskleidžia, kaip benamystę išgyvenantys vyrai taiko tam tikras išgyvenimo strategijas: siekdami gauti maisto lankosi labdaros valgyklose, maitinasi pas draugus, iš minimalių pajamų patys nusiperka produktų ar prašo išmaldos. Siekdami apsisaugoti nuo smurto vyrai stengiasi išlikti budrūs bet kuriuo paros metu, imasi „konfliktų gesintojo vaidmens“, būna drąsūs ir išdidūs, kai kyla grèsmè jų sveikatai. Noredami apsisaugoti nuo šalčio siekia įsigyti atitinkamų daiktų, susirasti atokesnes vietas, saugančias nuo vejjo ir šalčio.

PAGRINDINIAI ŽODŽIAI: benamystė, išgyvenimo strategijos, benamystės priežastys, naratyvas.
\end{abstract}

\begin{abstract}
This article analyzes the survival strategies of homeless men in the night shelters and in the street. Homeless people face social and economic lack of resources and because of that, their daily life is related with hope to meet their minimal needs: to find the shelter and food, to protect themselves from the cold and violence. The article presents empirical study the goal of which was to find out how the homeless people construct their hope to survive the homelessness on the streets and shelters. The results of the research show that homeless men use these survival strategies: in order to get food they go to the charity canteens, get food from their friends, try to buy food with their minimal incomes or beg in the streets. In order to protect themselves from the violence homeless men try to be open-eyed at any time of the day, take the role of "conflict fighter" or try to be brave and proud when there is a threat to their health. Trying to protect themselves from the cold homeless people look for the relevant things and find remote places to hide from wind and cold.
\end{abstract}

KEY WORDS: homelessness, survival strategies, reasons of homelessness, narration.

DOI: http://dx.doi.org/10.15181/tbb.v73i1.1272

\section{Ivadas}

Praktinis socialinis darbas pagrịstas vertybių sistema, kuri dažniausiai apima individo orumą ir vertę, apsisprendimo laisvę ir teisę i konfidencialumą. Su žmonèmis reikia elgtis pagarbiai, asmuo turi turèti galimybę valdyti savo gyvenimą, ji keisti, todèl turi būti pripažįstamas kaip unikalus individas, neskirstant pagal 
stereotipus. Socialiniai darbuotojai tiki įgimtu žmogaus orumu ir verte, o visuomenè privalo aprūpinti žmogų ištekliais ir paslaugomis, kad jis galètų tenkinti savo poreikius ir išvengti tokių problemų kaip skurdas, netinkamos gyvenimo sąlygos, badas, ligos, diskriminacija, benamystè, išstūmimas už visuomenès ribų (Morales, Sheator, 1987, cituojama iš Johnson, 2003).

Benamystė gali būti suprantama kaip socialinè atskirtis, kuriai būdingos kitos problemos ir sunkumai. Tai priklausomybès ligos, negalia, patiriamas smurtas, gyvenimas globos namuose, prostitucija, skaudūs vaikystės išgyvenimai. Yra daugybe ịrodymų, kad būtent šie rizikos veiksniai ir yra glaudžiai susiję su benamystès reiškiniu (Fitzpatrick, 2011, cituojama iš Manthrope, Cornes, O'Halloran, Joly, 2013). Todèl akivaizdu, kad benamystè - tai ne tik būsto neturejjimas, tai kompleksinis reiškinys, susijęs su tam tikrais asmeniniais sunkumais bei laiku ir tinkamai nesuteikta socialine pagalba.

Socialinio darbo profesija, įvairiais nacionaliniais ir tarptautiniais aktais siekiama apsaugoti žmogaus orumą, reglamentuoti ir teikti paslaugas, kurios leistų užtikrinti šią vertybę. FEANTSA (angl. European Federation of National Organizations Working with the Homeless) organizacija (2010) skelbia, kad šiuolaikinejje Europoje niekas neturètų būti priverstas miegoti gatvejje dèl to, kad neteikiamos aukštos kokybės paslaugos, kurios atitinka žmogaus poreikius, nepriimtina ir tai, kad žmonėms tenka patirti grèsmę savo sveikatai, saugumui ir ypač orumui. Lietuvoje laikino prieglobsčio paslaugas teikia nakvynès namai. Socialinių paslaugų, susijusių su benamyste, reguliavimas ir teikimas leidžia kalbėti apie modernios valstybẻs vystymą, formuojant ir performuojant socialinių paslaugų teikimo modelị. Tačiau toks socialinès politikos reguliavimas, kai benamystès problemoms spręsti trūksta paslaugų, jos yra neprieinamos ir / ar netinkamai reglamentuojamos, kai asmenų, gyvenančių nakvynès namuose ir gatvėse, skaičius išlieka didelis (Lietuvos statistikos departamento $2013 \mathrm{~m}$. duomenimis, 2012 metais nakvynès namų paslaugomis naudojosi 2447 žmonès, laikino apnakvindinimo paslaugomis - 5900 žmonių. Tuo tarpu 2013 metais nakvynès namuose gyveno 2601 žmogus, o laikino apnakvindinimo paslaugomis tais metais naudojosi 5040 žmonių), gali būti traktuojamas kaip neveiksmingas politikos priemonių ir paslaugų įgyvendinimas.

Benamyste ir išlikimas yra sudètingas išbandymas žmogui. Benamiams aktuali socialinių, ekonominių išteklių stoka, todèl jų kasdienis išgyvenimas pasireiškia siekiu ir viltimi patenkinti savo minimalius poreikius: susirasti pastogę ir maisto, apsisaugoti nuo šalčio ir smurto (Epel, Bandura, Zimbardo, 2006). S. L. Booth, J. Coveney (2008) teigimu, išgyvenimas gatvejje skatina asmenis imtis veiksmų, kurių jie niekada nebūtų èmęsi esant „,normalioms“ gyvenimo sąlygoms. Todèl išgyvenimas šiame straipsnyje įvardijamas kaip asmenų taikomos strategijos ir veiksmai, siekiant išgyventi benamystę. Benamyste žmones sukrečia, padaro juos 
silpnais, vis dèlto kiekvienas jų turi viltị gyventi geriau, todèl socialiniai darbuotojai, dirbdami su benamiais, turi stiprinti jų motyvacinį mąstymą, igalindami juos pradèti ir tęsti veiksmus, kurie suteiktų vilties ir skatintų siekti tikslo.

Lietuvoje mokslinių darbų, kur būtų tiriamas benamystės reiškinys, yra nemažai. Iš socialinio darbo perspektyvos benamystę tyrinèjo S. Verbauskienė (2010), A. Luneckienė (2007), I. Kipran (2006). Minètų autorių darbuose analizuojama benamių socialinė integracija ị visuomenę, jų asmenybès ypatumai, socialinių paslaugų poreikiai. Yra ir politikos mokslų, sociologų, psichologų atstovų (Indriliūnaitè, 2013; Sadauskas, 2010; Kocai, 2006, Vosyliūte, Kasparavičienè, Maniukaitė, 2004; Indriliūnaitè, 2009; Mikelionienè, Stankūnaitè, 2013; Petkevičiūtè, 2014; Vosyliūté, 2005, Kocai, 2008) darbų, kur tyrinėjami benamių socialiniai ryšiai, benamystès reiškinys, kasdienès benamių praktikos, benamystės reiškinio istorinè raida, veiksniai, nulėmę atitinkamą benamių gyvenimą, benamių stigmatizavimo ir kriminalizavimo klausimai, visuomenès atstumtujų vertybinės orientacijos bei jų formavimosi prielaidos. Lietuvos mokslininkų darbų, analizuojančių benamystę išgyvenimo kontekste, aptikti nepavyko. Tuo tarpu užsienio mokslininkų darbuose benamystè tyrinejjama ịvairiais aspektais - sveikatos, senatvès, tapatumo, maskulinizmo, socialinių paslaugų, politikos formavimo ir socialinio teisingumo kontekstuose (Hwang, 2001; Christensen, 2013; Hartnett, Postmus, 2010; Nyamathi, Leake, Gelberg, 2000; Bryan, Hammer, Fisher, 2000; Rowe, 2002; Anderson, Serpa, 2013; Watts, 2013; Bretherton, Hunter, Johnsen, 2013; Martinsson, Weiss, Zierler, 2013; Lindovska, 2014; Coker, Meyer, Smith, Price, 2010; Kore, Kiik, Boswinkel, 2006; Feher, 2011). Išgyvenimo strategijas analizuojančių mokslinių darbų aptikti nepavyko, todèl akivaizdu, kad tai nauja, mažai tyrinèta sritis.

Šio straipsnio tikslas - atskleisti, kaip benamiai vyrai konstruoja siekị išgyventi nakvynès namuose ir gatveje. Tyrimo objektas - išgyvenimo naratyvai vyrų benamystės kontekste. Tyrimo klausimai: ką reiškia būti benamiu ir gyventi pasaulyje, kuris kupinas kasdienių pavojų bei neigiamų visuomenés nuostatų; ką benamiams vyrams reiškia gebejimas susirasti maisto, apsisaugoti nuo šalčio, smurto, konkurencijos; kokias prasmes jie teikia šiems išgyvenimams? Iškelti probleminiai klausimai aktualūs tiek socialinio darbo teorinei, tiek ir praktinei perspektyvai, tam reikia tyrëjų dèmesio.

Tyrimas gali padèti geriau suprasti tiriamą reiškinį, numatyti pagalbos galimybes ar esamų socialinių paslaugų plètrą ir būtiną paramą, siekiant išsaugoti šių žmonių orumą bei vertę. Siekiant atsakyti $i \mathfrak{i}$ iškeltus probleminius klausimus atliktas kokybinis tyrimas, o duomenys analizuojami, remiantis naratyvine tyrimo strategija. 


\section{Tyrimo metodologija}

Duomenims rinkti ir apdoroti pasirinktas kokybinis tyrimas, kai individas nagrinèjamas ne kaip priklausomas nuo ịvairių socialinių dèsningumų, bet kaip unikali asmenybè, kuri turi savitą supratimą apie socialinę tikrovę, savitą savimonę ir per ją atskleidžia šią tikrovę, suteikia jai prasmę (Tidikis, 2003). Šiuo tyrimu siekiama ne verifikuoti, o atlikti mokslinę žvalgybą: aprašyti pasirinktą pažinimo objektą ir gautų duomenų pagrindu sukurti hipotetinį, tolesniam tikrinimui skirtą objekto modeli. Kita vertus, tyrëjas, remdamasis kokybiniu tyrimu, pirmiausiai siekia pateikti holistinị požiūrị ir tik tada pereiti prie analitinio aprašymo (Bitinas, Rupšienè, Žydžiūnaitè, 2008).

Kaip tyrimo strategija pasirinktas naratyvas. Naratyvinė metafora reiškia tai, kad žmogus patiria gyvenimą per savo paties gyvenimo istorijos pasakojimą. Ši tyrimo perspektyva leidžia tyrejjui ịsiklausyti ị žmonių pasakojamą patirtį, pamėginti ją suprasti, bet svarbiausia - ji leidžia pastebèti, kaip vis dèlto pats žmogus renkasi, ką pasakoti, kaip jis pats susieja savo patirties aspektus, vidinę ir momentinę patirtis (Combs, Freedman, 2012). Šis tyrimo metodas leidžia istorijoms suteikti reikšmes ir užpildo erdves tarp to, „kas vyksta“, ir „ką tai reiškia“ (Didion, 1961, cituojama iš Kramp, 2004). Daugialypès istorijos leidžia kalbèti apie daugialypes galimybes, sprendžiant iškilusias problemas. Svarbu pastebėti ir akcentuoti, kad naratyvinis tyrimo metodas remiasi tokiais aspektais, kurie atskleidžia, kaip žmonès, pasakodami savo patirties istorijas, suvokia savo pačiu gyvenimą, suteikdami jam tam tikras reikšmes.

Naratyvinio tyrimo metodas, tyrinejjant benamystę išgyvenančių vyrų patirtis nakvynès namuose ir gatvejje, leidžia pažvelgti ị problemą ir ją atskleisti ,iš vidaus“, išgirsti, pamatyti pačiu tiriamų asmenų požiūrị ị savo gyvenimą, orientuojantis ị prasmes, kurias jie teikia savo patirčių fiksavimui ir analizei. Žmogaus patirtis negali būti perduota kitiems, bet pasitelkus dialogą, interviu galima studijuoti prasmes, kurias jie teikia savo patirčiai. Pats žmogus analizuoja, stengiasi sukurti patyrimo reikšmę, kurią siekia papasakoti interviu gavejjui (Mikutavičienè, Šulskienè, 2012).

Iš dalies struktūruoti kokybiniai individualūs interviu atlikti 2015-01-222015-03-17. Tyrimui atlikti pasirinkta natūrali aplinka: interviu su tyrimo dalyviais vyko X nakvynės namuose, kur vyrai naudojasi laikino apgyvendinimo paslaugomis, ir X benamių dienos centre. Vyrai pasirinkti tikslingai, nes benamystę išgyvenančių vyrų statistinis skaičius didesnis negu moterų. Iš viso tyrime dalyvavo 9 vyrai: 4 vyrai, besinaudojantys laikino apgyvendinimo paslauga, 4 vyrai - laikino apnakvindinimo paslauga ir 1 - gyvenantis gatveje arba laikino apnakvindinimo namuose. Vidutinè interviu trukmè - 55 minutès. 
Kaip duomenų analizės metodas pasirinkta naratyvinė strategija. Naratyvinei analizei būdingas holistinis požiūris, kuris atskiras pasakojimo dalis susieja ị bendrą visumą. Tyrimo duomenų naratyvinè analizė atlikta remiantis G. Malinausko, M. Mozerytès (2011), R. Josselson (2011), C. Moustako (1994), C. Chapman (1994) (cituojama iš Partis, 2003) išskirtais etapais:

1) atidus interviu skaitymas, orientuojantis ị pasakojimo visumą;

2) skaitymas ir analizė kiekviena tema laiko dimensijos, paaiškinimo (angl. explanation) ir socialiniame / kultūriniame kontekste;

3) nustatytos prasmès susiejimas su teorija ir pristatymas.

Taigi analizuojant duomenis išgirstos žmonių istorijos suskaidytos ị segmentus; siekta suprasti tekstuose slypinčias prasmes; vèliau, laikantis holistinio požiūrio, dar kartą peržiūrèta visa gyvenimo istorija; galiausiai siekta aprašyti, remiantis teorinėmis žiniomis, kaip tam tikri gyvenimo momentai atskleidžia laiko, kultūrini ir socialini kontekstus. Svarbu pastebėti, kad pristatant tyrimo rezultatus vartojamos emic sąvokos, kuriomis siekta perteikti tyrimo dalyviu vartotas sąvokas, kalbantis apie išgyvenimus (Gončiarova, Ivanauskienė, 2013). Tyrime paryškintos kai kurios tyrimo dalyvių interviu ištraukos, siekiant atskleisti patirties unikalumą ir specifiškumą. Tyrimo rezultatų pateikimo dalyje naudota daug citatų, siekiant išryškinti subtilias benamių vyru patirtis, jas sutrumpinus nepavyktų iki galo perteikti unikalių tyrimo dalyvių išgyvenimų.

Tyrimas atliktas laikantis pagrindinių etikos principų, dèmesị skiriant tyrimo dalyvių požiūriui (Trochim, 2006, cituojama iš Bitinas, Rupšienè, Žydžiūnaite, 2008). Prieš atliekant tyrimą, jo dalyviams pristatytas tyrimo tikslas, uždaviniai ir jų teisès, taip siekiant užtikrinti laisvanoriškumo principą, kai tyrimo dalyvis pats sąmoningai ir laisvai apsisprendžia dẻl dalyvavimo. Vèliau, leidus atlikti tyrimą, tyrimo dalyviai informuoti, kad garantuojamas jų pateiktos informacijos konfidencialumas ir anonimiškumas (duomenų analizèje neminèti vardai, pavardès); vengta pateikti bet kokią informaciją, kuri galètų atskleisti asmens tapatumą. Vardai, pavardès ar kita svarbi informacija koduota pseudonimais. Tyrimo klausimai formuluoti subtiliai, siekiant nepažeisti, nepažeminti benamystę išgyvenančiu vyrų. Išgirdus pasakojimus, situacijas ir pastebejjus, kad pažeistas tyrimo dalyvio orumas, jaučiamas menkavertiškumo jausmas, vyrus siekta pastiprinti, akcentuojant jų stipriąsias puses. Benamiai žmonès dažnai jaučiasi neišgirsti, neturintys su kuo pasikalbèti, todèl tyrimo metu siekta, kad vyrai, dalindamiesi savo išgyvenimų patirtimi, jaustųsi svarbūs, daug išmanantys šioje srityje. Tyrimo dalyviams akcentuota, kad kilus neaiškumų, jie gali gauti atsakymus i jiems rūpimus klausimus. Tyrimo metu surinkti duomenys pateikiami autentiška tyrimo dalyvių kalba. 


\section{Tyrimo rezultatai}

Kelio ị tapsmą benamiu naratyvas: „Aš nesu išprotėjęs bohemos atstovas, tai man išbandymas, gyvenime pats sunkiausias" [Ąžuolas, 50]

Pasakodami apie savo gyvenimą tyrimo dalyviai dèmesį skyrè savo gyvenimui iki nakvynės namų. Analizuojant tyrimo dalyvių patirtis, išryškejjo sąryšingo naratyvo dalys pagal laiko dimensiją, paaiškinimą (angl. explanation) ir socialinį-kultūrinį kontekstą, kai vyrai siekè nusakyti veiksnius, kurie galèjo turèti lemiamos įtakos tampant benamiu. Tyrimo dalyvių paklausus, kaip jie supranta benamystę, daugelis vyrų benamystès sampratą konstravo neatsiedami jos nuo patekimo ị ši reiškinị priežasčių. Todèl pateiktas kelio ị tapsmą benamių naratyvas apima benamystès suvokimą vyrų akimis ir patekimo ị šị reiškinị priežastis.

\section{1 lentelè. Kelio ị tapsmą benamiu naratyvas}

Nesutarimai ir skyrybos su žmonomis / teistumas / netektys $\rightarrow$ būsto palikimas šeimai $\rightarrow$ draugai / pomėgiai / alkoholio vartojimas $\rightarrow$ pasirinkimas apsigyventi nakvynès namuose

Laiko dimensija: įvykiai dèliojami praeities perspektyvoje

Paaiškinimas (angl. explanation): nesėkmingai susiklostę santykiai praeityje, kalèjimas ir apsisprendimas išeiti iš namų ateityje lèmė tapimą benamiu

Socialinis-kultūrinis kontekstas: „Kada turi pinigų, tu visiems reikalingas, kada tu jų neturi - niekam nereikalingas“"

Pirmoji naratyvo dalis atskleidžia žmogaus gyvenimo pobūdị ir pomėgius iki tampant benamiu. Tam tikri rizikos veiksniai apibrèžia individo charakteristiką, kuri susijusi su socialiniu pažeidžiamumu, galinčiu turèti lemiamos įtakos benamystei žmogaus gyvenime. Tapimo benamiu rizikos veiksniai gali būti nulemti situacijos vaikysteje arba atsirasti suaugusiojo gyvenime (MacCratic, 2012). Interviu siekta sužinoti, kaip tyrimo dalyviai konstruoja benamystės sąvoką. Pirmoji duomenų analizè atskleidè, kad viena iš priežasčių, turejjusių lemiamos įtakos būsto praradimui, - vyro ir žmonos tarpusavio nesutarimai, dèl ko įvyksta skyrybos ir paliekamas visas užgyventas turtas: vestuvès $\rightarrow$ komandiruotè $\rightarrow$ skyrybos $\rightarrow$ turto palikimas žmonai. Įvykiai, nulèmę atsidūrimą gatvèje, Vakario istorijoje dèliojami praeities perspektyvoje:

$\mathrm{Nu}$, tai yra laiko tarpas toks ir viskas $<\ldots>$. Man benamyste yra keletas mėnesių. Tai yra laikinas dalykas. Taip, va, išèjo ir viskas. $<\ldots>$ tai aš palikau viską. Trijų kambarių butą. $\mathrm{Nu}$, taip atsitiko, taip atsitiko. Norejjo jinai... kaip norejjo, taip ir gyveno jinai. Dirbti nereikèjo. Aš ją paèmiau su vaiku, keturių mènesių... Mano klasioko sistra, kuris mire per auto avariją. Nu ir viskas, va, po skyrybų tie pardavinèjimai butu 
prasidejo. Aš iš Kaukazo atskridau, ten poilsiaudavau, kiekvienais metais ten skrisdavau. Tik atskridau, neužèjau pas tèvus net, namo, stovi... iš kur ji sužinojo, kad aš grįžau, nespejjau pas tèvus užeiti. Sako pasirašyti reikia. Žinai, turi praeiti trys metai, kad mano parašo reikia. Prašau, sakau, pasirašiau, daryk tu, ką nori [Vakaris, $50]$.

İdomu pastebėti, kad kalbėdamas apie priežastis, nulėmusias gyvenimą gatvèje, tyrimo dalyvis mažai kalba apie save. Istorijoje akivaizdžiai galima pastebėti dominuojantį žmonos norą skirtis ir Vakario nuolankumą („norejjo jinai“). Vakaris tarsi ịvardija prisiimtą aukos vaidmenį, pabrèždamas savo gailestị draugo sesei, kai ją ištiko nelaimingas įvykis ir ji liko viena su vaiku. Tuo tarpu benamyste konstruojama, siejant ją su laikotarpiu, kuris trunka keletą mėnesių (,laikinas dalykas"). Benamystès situaciją nulëmé pablogèję vyro ir žmonos tarpusavio santykiai. Tyrimo dalyvis atkreipia dèmesị ị socialinị kontekstą, nurodydamas, kad kiekvienais metais jis išvažiuodavo ị užsienị poilsiauti („Aš iš Kaukazo atskridau, ten poilsiaudavau, kiekvienais metais ten skrisdavau"). Galima daryti prielaidą, kad tokios „vienišos“ kelionès galèjo nepatikti jo žmonai, dèl ko ir galëjo įvykti skyrybos.

Ąžuolo naratyvas apie tapsmo benamiu priežastis pateikiamas praeities ir dabarties laiko dimensijoje, kai apie praeitị pasakojama esamuoju ir būtuoju kartiniu laikais. Kalbėdamas apie praeities įvykius, Ąžuolas tarsi pateisina savo dabartinę situaciją nurodydamas, kad ịvykiai yra tęstiniai. Kalbẻdamas apie benamystę ir jos priežastis, tyrimo dalyvis buvo nusiminęs:

Aš nesu išprotėjęs, bohemos atstovas, tai man išbandymas, gyvenime pats sunkiausias $<\ldots>$ čia reikia, aš nežinau, sugebèti, daug ką sugebėti, visko nori, absoliučiai visko nori ir nieko negauni. <..> Man tai yra košmaras, aš normalus žmogus, kaip ir visi, tik tiek, kad dabar, kai suaugęs esu, žinai, galiu pasakyti apie save, viską apie savo gyvenimą, gimiau netikusioje vietoje, netikusioje šeimoje, negavau visiškai jokio išsilavinimo, negavau žinių, kaip gyventi, nebuvo elementariausių dalykų, nebuvo padorumo, gyvenau grynai gatvẻje, nėra čia ko norèti. Tai va, tai čia iš tikro būtų debilizmas, kad aš pats iš savęs reikalaučiau daugiau, negu aš galiu [Azžuolas, 50].

Benamystė Ąžuolo istorijoje siejama su sunkiausiu išbandymu žmogaus gyvenime, kai jis negali patenkinti savo poreikių (,tai man išbandymas gyvenime pats sunkiausias"). Akivaizdu, kad šio tyrimo dalyvio gyvenimas nulemtas ne jo asmeninių pasirinkimų, lemiamos reikšmès suaugusiojo gyvenimui turèjo vaikystëje patirti išgyvenimai (kalëjimas, benamystè). A. Grušauskaitės (2012) atliktas tyrimas („Nuteistujų už labai sunkius nusikaltimus trauminio patyrimo ịvertinimas“) atskleidè, kad daugelio nuteistųų trauminè patirtis prasideda ankstyvoje vaikystėje, 
praradus tėvus ar kai jie nesirūpina savo vaikais, kai vaikai nuolat žeminami arba mato netinkamą tèvų elgesị. Ąžuolo patirtis atskleidžia, kad iki tampant benamiu, jis ilgą laiką praleido kalèjime, jo elgesio modelis išmoktas iš šeimos narių: „Gimiau netikusioje vietoje, netikusioje šeimoje, negavau visiškai jokio išsilavinimo, negavau žinių, kaip gyventi, nebuvo elementariausių dalykų, nebuvo padorumo, gyvenau grynai gatvèje, nèra čia ko norèti.“ Kalèjimas ir tapimas benamiu Ąžuolo istorijoje neatsiejami nuo vaikysteje išgyventų traumų, kurios nesudarẻ sąlygų pilnaverčiam suaugusiojo gyvenimui. Naratyvo socialinis kontekstas siejamas su socialiniais ryšiais tarp Ąžuolo ir jo biologinès šeimos.

Viljamo naratyvas, panašiai kaip ir Ąžuolo, atskleidžia, kad išèjimas iš kalèjimo, namų neturèjimas lėmè atsiradimą gatvèje (,,aš virš 20 metų praleidau kalèjime, suvoki“"). Be ịkalinimo, vyras vèliau pasakoja ir apie priklausomybę nuo alkoholio, dèl ko iš jo atimti vaikai. Pasak J. Petersilia (2001, cituojama iš Metraux, Culhane, 2004), sparčiai augantys įkalinimų skaičiai rodo, kad ịvairiose šalyse trūksta socialinių, ekonominių išteklių, siekiant veiksmingai kalinius reintegruoti ị visuomenę. Be to, benamystė yra rodiklis, kad trūksta ịvairių paslaugų: būsto suteikimo, pagalbos įdarbinant, psichosocialinių problemų sprendimo, elementarių socialinių paslaugų. Todèl benamystè ir ịkalinimas gali būti suprantami kaip vienas kitą lemiantys veiksniai: kaip benamystę išgyvenantis žmogus, praradęs viltị išgyventi, pradeda nusikalstamą veiką ir patenka ị ịkalinimo ịstaigą, kaip išèjęs iš ịkalinimo ịstaigos ir staiga atsidūręs gatvèje galimai grịžta prie nusikaltimų.

Skirtingai nei kiti tyrimo dalyviai, Viljamas benamystès socialinị konstruktą pateikè ne iš savo gyvenimiškosios patirties, bet iš kitų žmonių patirčių (,nu, aš žinau jų žmonas, ten ar pusę žinau apytiksliai“), iš to socialinio konteksto, kuriame jis gyvena:

žmona išvijo iš namų, vot, tokị pavyzdị, tris dienas vienas vyras pagyveno ir aš galiu pasakyti, kad dešimt sustatys vedusių ir, kad jisai benamis, batai nevalyti tas tas, o žmona taigi nuvalys arba privers jị. Vot, tau ir benamyste, kas reiškia, nèra šalia. Ir čia gi tas pats, ir čia gi tas pats. Žmona darydavo, nu, aš žinau jų žmonas, ten ar pusę žinau apytiksliai [Viljamas, 60].

Skirtingai negu prieš tai aprašytos patirtys, Erlando naratyvas atskleidžia, kad jo benamystė susijusi su besaikiu alkoholio vartojimu ir jo nulemtu ,kritimu žemyn". Priklausomybė ir benamystė yra vienas nuo kito neatsiejami reiškiniai. Pasak P. J. Fisher, W. R. Breakey (1991), alkoholio vartojimas siejamas su benamių praeities išgyvenimais: vaikystèje patirtais sunkumais ar traumomis, kurios vèliau galëjo turèti lemiamos ịtakos vartojant alkoholị. Kita vertus, priklausomybė nuo alkoholio vystosi tik vẻlesniuose žmogaus gyvenimo etapuose: ilgą laiką žmo- 
gaus gyvenimas būna stabilus, tačiau ịvykus sudètingesnei krizei ir nesugebant jos ịveikti pradedamas vartoti alkoholis. Erlando naratyvas taip pat atskleidžia, kad jam jaunysteje aktualesni buvo draugai ir alkoholis („Labai stipriai buvau pradèjęs alkoholị vartoti. Su draugais pradejjau alkoholį vartoti"), dèl ko vyras išsiskyrè su žmona ir pasirinko benamio gyvenimą:

Tai kasdienybė. Taip ir yra, kitaip nepavadinsi. Nieko nesikeičia, tos pačios dienos. $<\ldots>$ Išsiskyriau su žmona, ir tiek žinių. Viską ir palikau. Nebijojau išeiti ị nežinią. Man visiškai tas pats. Niekas to nekeičia. Pats vartodavau alkoholi, tai aišku... barai, klubai.<...> Labai stipriai buvau pradẻjęs alkoholị vartoti. Su draugais pradẻjau alkoholị vartoti [Erlandas, 42].

Erlando konstruojamas suvokimas apie benamystę leidžia daryti prielaidą, kad tyrimo dalyvis tarsi susitaikęs su esama padètimi. Paskiri žodžiai niekas nesikeičia, tos pačios dienos, tai kasdienybe atskleidžia, kad vyras nededa pastangų keisti esamą situaciją, tačiau pastaroji jo ir neglumina. Vèlesnejje istorijoje Erlandas teigia, kad turi mamą, pas kurią gali sugrįžti, tad benamystẻ šio žmogaus egzistencijoje yra gyvenimo būdas, kuris vyrui nesvetimas. Be to, draugams, o ne šeimai teikiama pirmenybè tik patvirtina, kad vyrui svarbiau mégautis laisve, nebūti ribojamam ir pajausti tą klajoklišką gyvenimo būdą.

Apibendrinus rekonstruotų istorijų ypatumus pastebėta, kad tyrimo dalyviai benamystės sampratą konstravo neatsiedami jos nuo šị reiškinį lèmusių priežasčių. Beveik visi tyrimo dalyviai naratyvus dèliojo praeities dimensijoje, išskyrus vieną tyrimo dalyvị, kuriam praeities ịvykiai svarbūs jo dabartinei situacijai ir emociniams išgyvenimams. Vyrai pabrèžè, kad benamystè - tai kasdienybė, kai žmogus neturi kur gyventi, apsistoti. Buvimas benamiu tyrimo dalyvių konstruojamas kaip sunkiausias išbandymas žmogui, kuris ji priverčia jaustis nelaimingu ir atstumtu. Vyrų patirtys atskleidè, kad pagrindinès priežastys, lèmusios jų tapsmą benamiais, susijusios tiek su subjektyviais, tiek su objektyviais veiksniais: vieniems tai buvo nesutarimai ir skyrybos su žmona, kitiems lemiamos įtakos turèjo teistumas bei laisvès atėmimas, dar kitiems - išgyventos netektys, nutrūkę socialiniai ryšiai. İdomu pastebèti tai, kad skyrybos, nelaimingai susiklostę santykiai daugelį tyrimo dalyvių paskatino išeiti iš namų, visą užgyventą turtą paliekant šeimos nariams. Išejimas iš namų, be abejonès, šių vyrų gyvenime nebuvo geriausias sprendimas: gyvenimas pas draugus ir alkoholio vartojimas lėmé jų tapimą benamiais ir apsigyvenimą nakvynès namuose. Tuo tarpu kitų tyrimo dalyvių naratyvai atskleidžia, kad visuomenè vis dèlto nẻra pasiruošusi priimti žmonių, kurie po įkalinimo išeina ị laisvę: laisvejje šių žmonių dažniausiai laukia benamystè. 


\section{Benamių vyrų vilties išgyventi gatvẻje ir nakvynès namuose naratyvas: „Tai yra kelionè per kopas“ [Vakaris, 50]}

Atlikto tyrimo duomenų analizė atskleidè, kad benamystė yra vienas sunkiausių išbandymų žmogui, nulemtas skirtingų priežasčių. Visuomenè dar nėra pasiruošusi priimti žmonių, kurie išgyvena socialinę atskirtį: pastebimos benamystę išgyvenančiu žmonių skaičiaus augimo tendencijos, iš kalëjimo grįžtantiems asmenims vis dar sunku reintegruotis ị visuomenę, dèl ko neretai buvę nuteistieji tampa benamiais. Buvimas benamiu nereiškia, kad žmogus tik turi susirasti pastogę ir patenkinti savo minimalius poreikius, tai kur kas daugiau. Benamystę išgyvenantys vyrai per trumpą laiką turi susirasti darbą, būti pakankamai finansiškai stabilūs, kad galètų išsinuomoti būstą, ,atsilaikyti“ prieš gatveje patiriamą smurtą, alkoholio vartojimą. Todèl šioje straipsnio dalyje siekiama atskleisti, kaip vyrai stengiasi išgyventi gatveje, kaip susiranda maisto, apsisaugo nuo šalčio, kaip konstruoja savo išlikimą. Svarbu akcentuoti, kad daugelio tyrimo dalyvių ịvykiai, lèmę dabartinị elgesị, konstruojami praeities perspektyvoje. Kitaip tariant, praeitis igauna dabarties formą ir leidžia daryti prielaidas, kad tyrimo dalyvių emocijos, patirtys dar neišgyventos.

2 lentelè. Išgyvenimo gatveje naratyvas

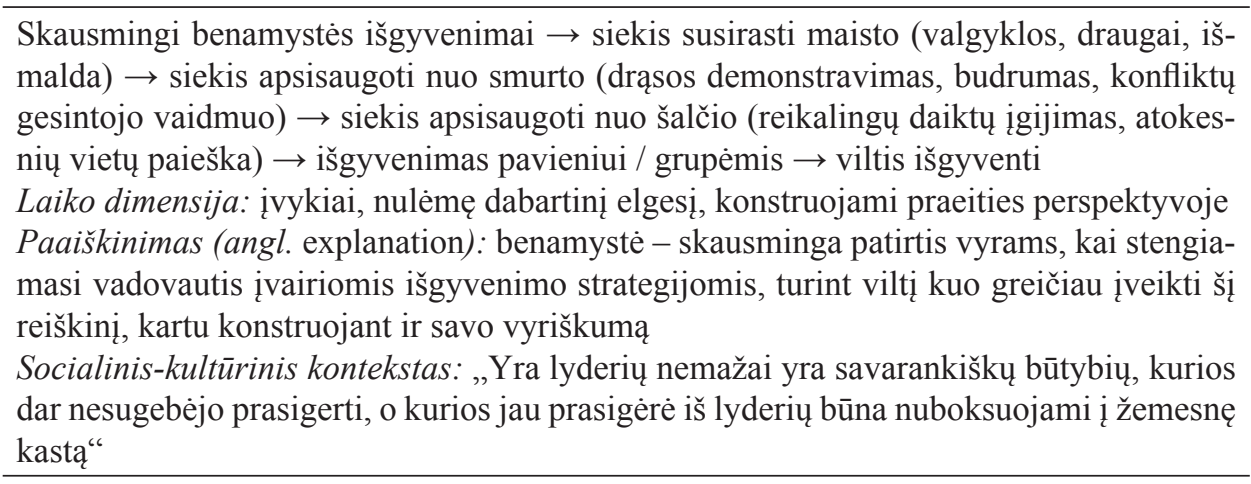

Kaip teigia M. Partis (2003), vieniems asmenims gyvenimas gatvejje yra sudètingas ir sukelia neigiamus jausmus, o kiti - priešingai, gyvenimą gatveje sieja su laisve, mėgaujasi tuo, ypač šis jausmas apima žmones vasarą. Ąžuolo naratyvas atskleidžia, kad jam benamystè sukelia skaudžius prisiminimus. Nepaisant to, kasdienè rutina apima tam tikrus dienos ritualus, rutiną, tai suteikia benamiams viltị išgyventi. Azžuolas taip pat siekia kuo greičiau išgyventi savo benamystę, todèl stengiasi susirasti darbą ir taupyti uždirbtus pinigus:

$<\ldots>$ pasiskambinu kažkur dèl darbo, dabar, va, paskutines savaites rimčiau. $<\ldots>$ nèra paprasta, jau galiausiai sakai dzin, viską skaičiuoju praktiškai iki sudilusio cento, 
suskaičiuoji viską, jeigu paskaičiuoji, kad kažkas netinkamai ir vèl atmetinèji, aš gi nesu beprotis, arba mazochistas, sadistas, kuriam patinka skausmas, arba kaifą sukelia kito žmogaus kančia [Až̌uolas, 50].

Pasak D. Farrugia (2010), benamiai žmonès dažnai apibrèžiami kaip tingūs asmenys, kuriems trūksta atsakomybès, ypač kai kalbama apie darbo rinką. Jie nesiekia aktyviai dalyvauti darbo rinkoje ir visuomenineje veikloje ir nerodo jokios motyvacijos. Tačiau Ąžuolo patirtis paneigia šį visuomenèje nusistovejjusį stereotipą: jis siekia išgyventi gatveje, susirasdamas darbą. İdomu pastebèti tai, kad motyvacijos nebuvimą, nenorą kažką keisti esamoje situacijoje Ąžzuolas apibūdina metaforiškai: „Aš gi nesu beprotis, arba mazochistas, sadistas, kuriam patinka skausmas, arba kaifą sukelia kito žmogaus kančia." Šie žodžiai patvirtina, kad benamyste žmogui yra sunkus išbandymas, tai lemia tam tikras pasekmes (pvz., beviltiškumą ar bejejgiškumą, kai nesiseka ịveikti benamystès), sukelia skausmą.

Tuo tarpu Viljamo istorija apie išgyvenimą gatvejje ypatinga. Nors šis tyrimo dalyvis turi darbą, santaupu, tačiau prireikus geba išgyventi prašydamas išmaldos, bet ne taip, kaip daugelis gatvejje matomų žmonių, bet vadovaudamasis tam tikra savita strategija:

Man todèl, man nèra problemų, man nėra problemų maistas. Aš galiu vot taip vot, trys namai, vot aš tau įrodyčiau tiesiog taip, jeigu reikètų, aš tau ịrodyčiau, nuosavi namai, prieičiau, vat, taip apsirengęs prieš kitus žmones: aš neturiu ką vaikam duoti valgyti, iš darbo, nu, bankrutavo firma, gal turite kokio darbo. $<\ldots>$ ateičiau pas žmones ir sakyčiau ar negalima pas jus žmonès tašytę ị sandèliuką padèt kur, pasakysiu, paskambinsiu, neturiu kur daiktų padèt. Supranti, nu, man akys nežiba. Ateiti pas žmones paprašyti valgyti, pasakyti ne tai, kad duokite prašau, aš alkanas, bet kita forma pasakyti. Visiem kainuoja, visi turi šeimas, vaikus savas problemas [Viljamas, 60].

Pasak S. L. Booth, J. Coveney (2008), maisto susiradimo praktika prašant išmaldos, atskleidžia tam tikras žmonių vertybes, tikejjimą ir standartus. Atsižvelgiant ị tai benamiai žmonès gali būti skirstomi ị dvi grupes: turintieji tvirtus moralès principus, kurių laikosi ir nepažeidinèja, ir tie, kuriems tam tikra moralè yra svarbi, bet noras valgyti vis dèl to verčia prašyti išmaldos. Viljamo patirtis tokią praktiką patvirtina. Nors vyras turi darbą, minimalių pragyvenimo lěšų, prireikus jis gali žmonių paprašyti pinigų maistui. Svarbu pastebèti, kad tyrimo dalyvis tai daro ne tiesmukiškai, bet taikydamas tam tikrą strategiją: „Aš neturiu, ką vaikam duoti valgyti.“

Tuo tarpu Taurui išgyventi padeda draugai: „Einu pas draugus, aš neklaidžioju taip, eisiu pas draugus, nueisiu ten, nueisiu ten.“ Tyrimo dalyvio istorijoje draugų pagalba yra kraštutinumas, paprastai Tauras stengiasi išgyventi pasitelkdamas savo ịgūdžius ir gebẻjimus, susidarydamas tam tikrą dienotvarkę: 
galvoju visą laiką, išgyventi tai reikia. Visi draugai, šeimos niekad nieko neprašiau ir nieko neprašiau, durnas vyriškas, durnas, čia aišku, bet ne... O šiaip tai, kaip pasakyti, daug kas stebisi, kaip aš išgyvenu. Stebisi, tegu stebisi. $<\ldots>$ čia dabar reikia galvoti, pastoviai galvoti... o šiaip tai sveikata nesiskundžiu, o šiaip tai sunku... $<\ldots>$ Mane jau pamokino, be dokumentų likau, be paso, be piniginès, be pinigų, ir nujaučiu, kas tai padarè, bet negaliu ịrodyti <..> aš buvau bare, tam bare pavalgiau, išgèriau, išèjau ir neatsimenu, kaip nukritau. $\mathrm{O}$ kai atsikèliau, jau nieko nèra. Nu, kažkaip tai aš savisaugos instinktą tai turiu, o išejjau aš tai parūkyti ir tiek $<\ldots>$ nu, aš šiaip tai pastoviai darbą kažkoki randu. Negaliu be darbo. Randu tai ten, tai ten, nes vis tiek riekia gyventi, reikia valgyti. Negali visai nieko... pinigų niekas neduoda, niekas nė karto nedavé, ir jums neduos net. Tikrai neduos, taip, kad ir man niekas neduoda, nu, gali vieną kitą kartą duoti, nu, bet tai pačiam negražu [Tauras, 64].

Tauro istorija atskleidžia, kad pagalbos iš artimųų ir draugų prašymas siejamas su vyriškumo menkejjimu. Pagalbos prašymas tarsi parodo, kad žmogus silpnas ir negali savimi pasirūpinti. Be to, Tauras benamystės konstruktą sieja ir su žmogaus kalte atsidūrus tokioje situacijoje. Todèl galima daryti prielaidą, kad pagalbos iš savo artimųų atsisakymas reiškia ne tik savo vyriškumo demonstravimą (,durnas vyriškas, durnas“), tai kartu ir noras pačiam dèl savo kaltės ,kritus žemyn“ sugričži i pradinę padèti. Tyrimo dalyvio istorija taip pat atskleidžia, kad jam teko susidurti su smurtu gyvenant gatvėje (,Mane jau pamokino, be dokumentų likau, be paso, be piniginès, be pinigư"'), tačiau tokia ịgyta patirtis siejama su tam tikrų igūdžių lavinimu, kurie vèliau padeda žmogui išgyventi - gyvendamas gatvèje žmogus turi būti nuolat budrus. Pasak M. K. Fitzpatrick, E. M. LaGory, J. F. Ritchey (1999) ir L. R. Simons, B. L. Whitbeck (1991, cituojama iš Lee, Schreck, 2005), benamiams žmonèms, kurie daug laiko praleidžia gatvėse tiek dieną, tiek naktị atsiranda grèsmė tapti įvairaus pobūdžio nusikaltimo aukomis.

Skirtingai nei kiti tyrimo dalyviai, Vakaris atvirai pasakojo, kaip jam pavyksta išgyventi gatvejje. Kalbėdamas apie maisto paieškas, jis, panašiai kaip ir Viljamas, turi savitą strategiją:

$\mathrm{Nu}$, koks gyvenimas, reikia išgyventi sugebėti. $<\ldots>$ aišku išgyventi. Nu vot, aš neturiu nei cento. Nu ir už ką aš valgau? Reikia išgyventi... Reikia suktis... Vogti aš nevagiu, man šimtą metų nereikia. Žmonès duoda. <..> Aš ne tai, kad išmaldos prašau. Pas mane vis tiek kitokia sistema. Nu va, aš, pavyzdžiui, turiu 10 centų. Aš einu i parduotuvę, einu nesvarbu ten ị „Norfą“, „Iki““, koks skirtumas. Einu, užeinu, paimu batoną, paimu, ką man pavalgyti reikia, man, sakau, trūksta, galite duoti 10 centų, 15 centų. Kas litą duoda, kas 20 centų duoda, kas nieko neduoda. Nu, trūksta, sakau, ant maisto, neturiu, sakau, tiesiai šviesiai. < ..> Vakar, va,vienas krapštė krapštè, sako neturiu, imk eurą. Davė eurą... Kas kiek gali, nesvarbu ar 10, ar 6... nu, tai susirenka gi... O aš sau kraunu po biški maisto, paskaičiavau, kiek pas mane yra, ką man dèti, ir viskas. Ir vèl, ir neišeinu, sukuos salèj, pastoviai [Vakaris, 50]. 
Vakario istorijoje aiškiai įvardijama, kad siekiant išgyventi, reikia mokèti tai daryti (,reikia išgyventi sugebèti“, „reikia suktis“). İdomu pastebèti, kad, nors benamystę išgyvenantiems žmonèms trūksta tam tikrų dalykų, jie negali patenkinti savo pagrindinių poreikių, visgi jų moralumas ir atsakomybė neleidžia jiems imtis nusikalstamos veikos („Vogti aš nevagiu, man šimtą metų nereikia“), kokia prasta jų padètis bebūtų. Toks šių žmonių pasirinkimas yra pagirtinas: nors žmonės ị juos žiūri niekinamai, jie sugeba būti stiprūs ir priimti sprendimus net pamindami savo orumą (išmaldos prašymas), bet nesiima amoralių veiksmų. Vakaris, siekdamas gauti maisto, taiko savitą strategiją - prašo išmaldos. Tyrimo dalyvis nesėdi gatvèje, prašydamas, kad jam paaukotų centų, bet vaikšto po parduotuves prašydamas ir bandydamas įrodyti, kad pinigu jam reikia maistui („,man, sakau, trūksta, galite duoti 10 centų, 15 centų"). Atliekant tyrimą pastebèta, kad dèl nepakankamų finansinių išteklių Vakario valgymo ịpročiai taip yra pakitę: „Aš iš ryto niekada nevalgau“. Be maisto paieškos, Vakariui tenka rūpintis ir savo nakvyne. Tyrimo dalyvio teigimu, jam dažnai tenka miegoti gatveje: „Šiandien, pavyzdžiui. Prieš tai tris naktis iš eilès.“ Miegant gatveje, ant suolelių (,aš lauke miegu“), taip pat reikia tam tikros išgyvenimo strategijos:

$<\ldots>$ aš lauke miegu. Galit paklausti, stotelejj, va. $<\ldots>$ Paimi putos, po šikna pasidedi, jinai šilumą duoda gerą, nes suoliukai taigi ką... stotelèj po stogu, bet traukia labai stipriai, tai va nenori susirgti... <..> Turiu savo vietas... Paslepiu, kad nepaimtu ir vsio. Neišmestų... Nieko čia baisaus. Paskui būna pas draugus pernakvoju, nakvynkèj. İvairiai būna [Vakaris, 50].

Tam tikrų daiktų, kurie padeda apsisaugoti nuo šalčio, turejimas skatina tyrimo dalyvị susirasti atokesnes vietas, kur jis galètų paslëpti savo nakvynès reikmenis. Vakariui netenka nuolat miegoti gatvejje, kartais jis pasinaudoja nakvynės namų paslaugomis, draugu pagalba. Pasak N. Dachner, V. Tarasuk (2002), miegant viešose vietose benamystę išgyvenantiems žmonėms tenka turèti reikalų su policija. Miegojimas ar vaikščiojimas naktimis miesto gatvėmis, be abejonès, policijai sukelia įtarimų, todėl benamiai žmonès sustabdomi. Vakario patirtis taip pat atskleidžia, kad jam teko susidurti su policijos pareigūnais:

Paklausè: „,dokumentus turi?“, „turiu“, „paieškomas?“, „, net nesėdèjęs, sakau, niekam nereikalingas, sakau, pasijuokiau“. Patikrino per kompą ir viskas, nu ir vsio, tiek žinių. Sakau, nèr kur pasidèti [Vakaris, 50].

Skirtingai nuo kitų tyrimo dalyvių, Rapolo patirtis atskleidžia, kad vyrai laikino apgyvendinimo namuose stengiasi išlikti kaip grupè: 
Pagrinde, pasižiūrèk, beveik visi buvo vedę, beveik visi turèjo namus, dabar, pasižiūrèk, visi pensininkai čia arba invalidai, arba vienas kitas iš zonos grịžęs. Nu ir... taip ir čia tas pats. Žmogus nepatiko, tu su juo nenori bendrauti, tai ką tu su juo eisi, kaip ten sakant ị... Nu ačiū, atleisk, laba diena, viso gero. $<\ldots>$ Yra kaimynai, su kuriais nori nenori bendrauji. Yra vieni, su kuriais normaliau bendrauji, yra kiti, kurie patys jiems neaktualu, jie nenori. < ..> Čia, žinok, vienas lauke ne karys, jeigu tu užsisklęsi, būsi vienas, be apvalkalèlio. Bet ne kiekvienas sugeba. Kitas užsisklendžia, bet jisai ilgai netempia, žinot, užsisklendžia, o paskui nervus nuramint ir paskui pasibaigia visi tie...ị dugną, ị dugną, ị dugną [Rapolas, 48].

Rapolas, skirtingai negu kiti tyrimo dalyviai, apie draugus nekalbejjo. Todèl akivaizdu, kad jis su nakvynès namų gyventojais palaiko draugiškus ryšius. L. Rew (2000) atliktas tyrimas ("Without Parental Consent: Conducting Research with Homeless Adolescents") atskleide, kad tie, kurie jaučiasi vieniši būdami benamiai, nurodo, kaip išvengti šio jausmo. Galima susirasti žmogų, draugą, su kuriuo gali pabendrauti, arba įsigyti augintinị. Akivaizdu, kad gyvenant nakvynès namuose turèti augintinị nèra galimybès, tad ryšiai palaikomi su ten gyvenančiais asmenimis. Rapolas patvirtina mokslines įžvalgas, kad vienišumo jausmas gali sukelti skaudžius išgyvenimus (,,kitas užsisklendžia, bet jisai ilgai netempia $<\ldots>$ i dugną, ì dugną, ì dugną").

Apibendrinant galima teigti, kad tyrimo dalyviai, kad išgyventų benamystę, taiko tam tikras strategijas. Tyrimo dalyvių rekonstruoti naratyvai atskleide, kad benamystę išgyvenantys žmonès nèra tingūs ar nemotyvuoti asmenys, atvirkščiai, jų vertybės, moralumas ir atsakomybė visuomenei neleidžia jiems imtis nusikalstamos veikos, nors ir trūksta tam tikrų dalykų, kurie padètų patenkinti minimalius poreikius. Užuot vykdę nusikaltimus, jie imasi tam tikrų išgyvenimo strategijų. Siekdami gauti maisto, vieni tyrimo dalyviai naudojasi valgyklomis, teikiama labdara, valgo pas draugus, kiti, kurie gauna vienokias ar kitokias pajamas, stengiasi maisto nusipirkti, dar kiti prašo išmaldos. Antrasis tyrimo dalyvių naratyvas atskleidè, kad benamystę išgyvenantys asmenys susiduria su smurtu tiek gatvèje, tiek nakvynès namuose. Siekdami išvengti vienokio ar kitokio fizinio smurto, tyrimo dalyviai taiko tam tikras strategijas: vieni sako, kad svarbu būti budriam, kiti imasi konfliktų „gesintojo“ vaidmens, dar kiti teigia, kad svarbu turèti drąsos ir „pastovèti“ už save. Benamiai žmonès susiduria ir su padidejusia rizika fizinei sveikatai dèl šalčio. Siekdami apsisaugoti jie stengiasi kuo daugiau judèti, susirasti atokesnes vietas ir įsigyti atitinkamų daiktų, kurie juos apsaugotų. Vienatvė benamių žmonių gyvenime - daugeliui pažistamas jausmas. Atsižvelgiant ị tai, kaip jaučiasi - vieniši / nevieniši, jie konstravo ir sampratą, kaip benamiai išgyvena: pavieniui ar kaip grupè. Tie respondentai, kurie turi draugų, benamystę išgyvena pavieniui. Tuo tarpu tie asmenys, kurie už nakvynès namų ribų nepalaiko socialinių ryšių, benamystę išgyvenančius žmones įvardijo kaip grupę. 


\section{Išvados}

1. Benamystę tyrimo dalyviai apibrěžè kaip patị sunkiausią ir daugiausiai pastangų reikalaujantį išbandymą žmogui. Vyrai pabrèžè, kad tai praeityje netinkamai susiklosčiusių aplinkybių padarinys. Pagrindinès priežastys, lėmusios tyrimo dalyvių tapsmą benamiu, susijusios ir su subjektyviais, ir su objektyviais veiksniais: vieniems tai buvo nesutarimai šeimoje ir skyrybos su žmona, kitiems lemiamos įtakos turèjo teistumas ir laisvės atėmimas, dar kitiems - išgyventos netektys ir nutrūkę socialiniai ryšiai. Šios priežastys lėmè tyrimo dalyvių išèjimą iš namų - į gatvę, pas draugus, viską paliekant savo šeimos nariams.

2. Vyrų praktinė patirtis pagrindžia teoriją, kad buvimas benamiu nereiškia vyriškumo praradimo. Tai kasdienè kova už savo būvị ir gerovę, kuria siekiama ịveikti kylančius pavojus, susidūrus su nesaugumu ir nenuspejjamumu. Benamių vyrų puoselëjamos vertybès, moralumas ir atsakomybė visuomenei neleidžia imtis nusikalstamos veikos, net jei jie išgyvena skurdą ir negali patenkinti minimalių poreikių. Užuot vogę, kas, tyrimo dalyvių teigimu, būtu paprasčiau, jie imasi tam tikrų išgyvenimo strategijų. Siekdami patenkinti pagrindinius savo poreikius (maisto, saugumo) vyrai maistą perka patys, lankosi labdaros valgyklose, maitinasi pas draugus, prašo išmaldos, kas pamina jų orumą. Tuo tarpu norėdami apsisaugoti nuo smurto, visada stengiasi išlaikyti budrumą, turèti drąsos apginti save ar imtis konfliktų ,gesintojo“ vaidmens.

3. Vienatvè benamių žmonių gyvenime - daugumai pažistamas jausmas. Tie, kurie jaučiasi vieniši būdami benamiai, nurodo, kad jie išgyvena kaip grupe, vieni su kitais palaikydami socialinius ryšius, prireikus teikdami vieni kitiems pagalbą. Kita tyrimo dalyvių dalis atskleidè, kad jie nesiekia išgyventi kaip grupé, o labiau kaip pavieniai asmenys. Jiems pagalba iš tokio pat likimo žmonių neprasminga ir nereikalinga, nes palaiko socialinius ryšius su draugais, kurie nèra benamiai ir gali padèti finansiškai.

Gauta 20151212

Pasirašyta spaudai 20160307

\section{Literatūra}

Anderson, I., Serpa, R. (2013). The Right to Settled Accommodation for Homeless People in Scotland: A Triumph of Rational Policy-Making? European Journal of Homelessness, Vol. 7, No. 1, p. 13-41.

Bitinas, B., Rupšienè, L., Žydžiūnaitè, V. (2008). Kokybiniu tyrimų metodologija: vadovélis vadybos ir administravimo studentams. Klaipėda: „Nemuno“ spaustuvè.

Booth, L. S., Coveney, J. (2008). Survival on the Streets: Prosocial and Moral Behaviors Among Food Insecure Homeless Youth in Adelaide, South Australia. Journal of Hunger \& Environmental Nutrition, Vol. 2(1), p. 41-53. 
Booth, L. S., Coveney, J. (2008). Survival on the Streets: Prosocial and Moral Behaviors Among Food Insecure Homeless Youth in Adelaide, South Australia. Journal of Hunger \& Environmental Nutrition, Vol. 2(1), p. 41-53.

Bretherton, J., Hunter, C., Johnsen, S. (2013). 'You can judge them on how they look...' Homelessness Officers, Medical Evidence and Decision-Making in England. European Journal of Homelessness, Vol. 7, No. 1, p. 69-93.

Bryan, D. A., Hammer, C. J., Fisher, D. F. (2000). Whose Hands Reach Out to the Homeless? Patterns of Helping Among High and Low Communally Oriented Individuals. Journal of Applied Social Psychology, Vol. 30, 5, p. 887-905.

Christensen, J. (2013). "Our home, our way of life": spiritual homelessness and the sociocultural dimensions of Indigenous homelessness in the Northwest Territories (NWT), Canada. Social \& Cultural Geography, Vol. 14, No. 7, p. 804-828.

Coker, D. A., Meyer, D., Smith, R., Price, A. (2010). Using Social Justice Group Work With Young Mothers Who Experience Homelessness. The Journal for Specialists in Group Work, Vol. 35, p. 220-229.

Combs, G., Freedman, J. (2012). Narrative, Poststructuralism, and Social Justice: Current Practices in Narrative Therapy. The Counceling Psychologyst, Vol. 40(7), p. 1033-1060.

Dachner, N., Tarasuk, V. (2002). Homeless "squeegee kids": Food insecurity and daily survival. Social Science and Medicine, Vol. 54, p. 1039-1049.

Epel, S. E., Bandura, A., Zimbardo, G. (2006). Escaping Homelessness: The Influences of Self-Efficacy and Time Perspective on Coping With Homelessness. Journal of Applied Social Psychology, Vol. 29 (3), p. 575-596.

Farrugia, D. (2010). The symbolic burden of homelessness Towards a theory of youth homelessness as embodied subjectivity. Journal of Sociology, Vol. 47(1), p. 71-87.

FEANTSA. Panaikinti benamyste yra immanoma! Prieiga internete: http://www.feantsa.org/spip. php?action=acceder_document $\&$ arg $=561 \& c l e=f 91 \mathrm{db} 52718 \mathrm{ce} 5 \mathrm{~b} 9 \mathrm{cc} 5184 \mathrm{f} 757 \mathrm{c} 251 \mathrm{c} 6225 \mathrm{c} 18 \mathrm{adb} \& \mathrm{file}=\mathrm{pdf}$ \%2Ffea_001-09_tt.pdf [žiūrèta 2016-02-05].

Feher, B. (2011). Understanding the Homeless Experience in Hungary through a Narrative Approach. European Journal of Homelessness, Vol. 5, No. 1, p. 49-67.

Fischer, J. P., Breakey, R. W. (1991). The Epidemiology of Alcohol, Drug, and Mental Disorders Among Homeless Persons. American Psychologist, Vol. 46, Nr. 11, p. 1115-1128.

Gončiarova, N., Ivanauskienė, V. (2013). Benamių vyrų patirtys: atvejai iš nakvynès namų. Socialinis darbas. Patirtis ir metodai, Vol. 12(2), p. 65-89.

Grušauskaitė, A. (2012). Nuteistụjų už labai sunkius nusikaltimus trauminio patyrimo ịvertinimas. Socialinis ugdymas, Nr. 21 (32), p. 112-122.

Hartnett, P. H., Postmus, L. J. (2010). The Function of Shelters for Women: Assistance or Social Control? Journal of Human Behavior in the Social Environment, p. 289-302.

Hwang, W. S. (2001). Homelessness and health. Canadian Medical Association Journal, Vol. 164, No. 2, p. 229-233.

Indriliūnaitè, R. (2009). Kriminalinė subkultūra už įkalinimo įstaigos ribų: benamiai, buvę nuteistieji. Grupés ir aplinkos, Nr. 1, p. 127-141.

Indriliūnaitè, R. (2013). Benamystè Lietuvoje: nakvynès namu gyventojų (iš)gyvenimo praktikos. Daktaro disertacija. Kaunas: VDU.

Johnson, C. L. (2003). Socialinio darbo praktika: bendrasis požiūris. Vilnius: VU specialiosios psichologijos laboratorija.

Kipran, I. (2006). Benamių asmenybès ypatumai. Magistro baigiamasis darbas. Vilnius: VPU.

Kocai, E. (2006). Benamystė kaip socialinis reiškinys. Filosofija. Sociologija, Nr. 2, p. 53-62.

Kocai, E. (2008). Socialinè benamių atskirtis ir jos formavimasis. Sociologija. Mintis ir veiksmas, Nr. 1, p. 105118 .

Kore, J., Kiik, R., Boswinkel, E. (2006). Homelessness in Estonia - Problem of the Individual or the Society? International Journal of Housing Policy, Vol. 6, p. 297-312.

Kramp, K. M. (2004). Exploring Life and Experience through Narrative Inquiry. Foundations for Research - Methods of Inquiry in Education and the Social Sciences.

Lee, A. B., Schreck, J. Ch. (2005). Danger on the Streets Marginality and Victimization Among Homeless People. American Behavioral Scientist, Vol. 48, Nr. 8, p. 1055-1081.

Lietuvos statistikos departamentas. (2013). Informacija: socialinès paslaugos 2013. Prieiga internete: http:// www.socmin.lt/download/8480/informacija_soc_paslaugos_2013.pdf [žiūrèta: 2016-02-05].

Lindovska, A. (2014). Housing Homeless People in Europe. European Journal of Homelessness, Vol. 8.1, p. $97-115$. 
Luneckienè, A. (2007). Benamiu socialine integracija i visuomene. Magistro baigiamasis darbas. Vilnius: VPU.

MacCratic, M. R. (2012). Criminal Interventions with Homelessness: Risk Factors for Incarceration among the Service Seeking Homeless in San Diego. Master thesis.

Malinauskas, G. Mozerytė, M. (2011). Paauglių išgyvenimai tèvams dirbant užsienyje: naratyvinis reiškinio suvokimo būdas. Kultūra ir visuomenè, Nr. 2(1), p. 61-78.

Manthrope, J., Cornes, M., O’Hallora, S., Joly, S. (2013). Multiple Exclusion Homelessness: the Preventive Role of Social work. British Journal of social work, Nr. 7, p. 1-13.

Martinsson, S., Weiss, T., Zierler, A. (2013). Accommodating Homeless Families in the Private Rented Housing Sector: Experiences from a Supported Housing Project in Vienna. European Journal of Homelessness, Vol. 7, No. 1, p. 117-135.

Metraux, S., Culhane, P. D. (2004). Homeless Shelter use and Reincarceration Following Prison Release. Criminology \& Public Policy, Vol. 3, p. 139-160.

Mikelionienė, M., Stankūnaitė, G. (2013). Benamystè kaip socialinès atskirties raiška: „, $N$ “ nakvynès namu atvejis. Prieiga internete: https://ojs.kauko.lt/index.php/ssktipd/article/view/431 [žiūrèta 2016-02-05].

Mikutavičienė, I., Šulskienė, R. (2012). Metadono programos veiksmingumo vertinimas: subjektyvios gyvenimo kokybės paradigma. Sveikatos mokslai, Vol. 22, No. 5, p. 64-70.

Nyamathi, M. A., Leake B., Gelberg, L. (2000). Sheltered Versus Nonsheltered Homeless Women. Differences in Health, Behavior, Victimization, and Utilization of Care. Journal of General Internal Medicine, Vol. 15, p. $565-572$.

Partis, M. (2003). Hope in homeless people: a phenomenological study. Primary Health Care Research and Development, Vol. 4, p. 9-19.

Petkevičiūtė, R. (2014). Socialinės atskirties kriminalizavimas: ịkalinimo patirties turinčių benamių atvejis. Kultūra ir visuomene. Socialiniu tyrimu žurnalas, Nr. 5 (2), p. 85-104.

Rew, L. (2000). Friends and Pets as Companions: Strategies for Coping with Loneliness Among Homeless Youth. Journal of Child and Adolescent Psychiatric Nursing, Vol. 13(3), p. 125-132.

Rowe, J. (2002). Survival Strategies of the Homeless and Drug Dependent: 'Don't Wander Around In Bare Feet' the Squatting Experience. Paper presented at the Housing, Crime and Stronger Communities Conference convened by the Australian Institute of Criminology and the Australian Housing and Urban Research Institute and held in Melbourne, p. 1-13.

Sadauskas, J. (2010). Socialinis darbas su benamiais. Sud. J. R. Šinkūnienè. Socialinis darbas: profesinè veikla, metodai ir klientai: vadovélis. Vilnius: Mykolo Romerio universitetas, p. 483-507.

Tidikis, R. (2003). Socialiniu mokslu tyrimu metodologija. Lietuvos teisès universitetas.

Verbauskienè, S. (2010). Laikino apnakvindinimo ir laikino apgyvendinimo nakvynès namu vyru socialiniu paslaugu poreikiai. Magistro baigiamasis darbas. Kaunas: VDU.

Vosyliūtė, A. (2005). Vargetos: ieškant gyvenimo sąlygų ir savęs. Socialinis darbas, Nr. 4(2), p. $33-41$.

Vosyliūtè, A., Kasparavičienè, V., Maniukaitė, G. (2004). Varguomenė: gyvensena ir vertybès. Socialinių tyrimų institutas.

Watts, B. (2013). Rights, Needs and Stigma: A Comparison of Homelessness Policy in Scotland and Ireland. European Journal of Homelessness, Vol. 7, No. 1, p. 41-69.

\title{
MEN'S HOMELESSNESS IN THE NIGHT SHELTERS AND IN THE STREET: NARRATIVES OF SURVIVAL
}

\author{
Violeta Ivanauskienė, Natalja Gončiarova
}

Summary

Homelessness has always been an important issue in any state and society. It is a complicated phenomenon because of which people lose their dignity, experience 
violation of their rights and personal crises. The European Federation of National Organizations Working with the Homeless (2010) states that in modern Europe nobody should sleep in a street because of the lack of the high-quality services which should be compatible with the needs of any person. It is also not acceptable that people experience harm to their health, safety and, especially, dignity. The more people are involved in the public life, the more development of Europe will be promoted. Thus, concerning all the mentioned aspects, the state must ensure rights of homeless people and protect their dignity. Control and implementation of social services in the area of homelessness lead to the wider development of the modern state, shaping and re-shaping the model of providing social services. Homeless people face the lack of social and economic resources, so their everyday survival is trying to meet the minimal needs: to find shelter and food; to protect themselves from cold and violence. Homelessness makes people weak and uncertain but nevertheless, each person has the hope to live better, so social workers, while working with the homeless, have to strengthen their motivation and empower them to act pursuing their hope and goal.

The qualitative research has been conducted in order to better understand the phenomenon of homelessness and identify the main problems that homeless men experience. According to the qualitative research method, an individual is seen not as dependent on different social regularities but as a unique personality, who has original understanding of social reality. The aim of the research is to show how homeless men construct hope to survive in the night shelters and in the streets. The following research questions have been raised: what does it mean to be a homeless person and live in the world facing daily dangers and society's negative attitude? What is the meaning of capacity to find food, protect oneself from cold, violence, competition? The research is based on the position of subjective - interpretive epistemology. In order to reveal the narratives of homeless men, semi-structured qualitative interview has been chosen. 9 participants (42-72 years old) took part in the research. The interviews were conducted in research participants' natural environment: in X night shelter and in X day center for homeless people. Average interview duration was 55 minutes.

The analysis of collected data was based on the method of narrative strategy. This analysis allows the researcher to listen to research participants attentively trying to understand their life experiences. Holistic attitude is characteristic for narrative analysis as it integrates separate parts of the narration into overall unit. The following stages of the analysis were used: attentive reading of an interview, stressing the wholeness of the narration; reading and analyzing each theme of the interview in time dimension, explanation and in social / cultural context; associating the meanings with theoretical background and then presenting them. It is also 
important to point out that presenting research findings emic concepts are used. These concepts help to convey notions used by research participants when they talked about their life experiences. Presenting research findings many quotations are used so as to highlight sensitive and unique experiences of the homeless men.

The research was conducted following main ethical principles: the research aim, objectives were presented before the interview; research participants were informed about confidentiality and their right to take part in the research or not.

According to the results of the research, in the practical context, homelessness is constructed as the most difficult and the most effort-requiring task for a person. It is determined by various objective and subjective factors. Adopted moral values and social responsibility require that homeless men should not commit crime but survive and satisfy the minimum needs by following certain strategies. The results of research have shown how homeless men construct their hope to survive the homelessness by using some survival strategies. Homeless men, who seek to get food go to the charity canteens, eat in their friends' homes, try to buy food from their minimal incomes or beg in the streets. In order to protect themselves from the violence, homeless men try to be open-eyed at any time of the day, take the role of a "conflict fighter" or try to be brave and proud when there is a threat to their health. In order to protect themselves from the cold homeless people seek to acquire the relevant things and find remote locations to hide from wind and cold.

During the research, it has been found out that the men try to survive not only as a group but also as individuals. In the life of homeless men, existence is related to the power of faith and help for each other. The hope to survive is related to certain strategies of survival and expectations to lead a better life in the future. 
